\title{
Relationship between the perceived social support and catastrophization in individuals with chronic knee pain
}

\author{
Relação entre suporte social percebido e catastrofização em indivíduos com dor crônica do joelho
}

Bruna Almeida1 , Adriana Capela¹, Joana Pinto ${ }^{1}$, Vânia Santos¹, Cândida G. Silva ${ }^{1,2}$, Marlene Cristina Neves Rosa ${ }^{3}$

DOI 10.5935/2595-0118.20190011

\section{ABSTRACT}

BACKGROUND AND OBJECTIVES: Catastrophization and social support influence health outcomes in people with chronic pain. However, there is still no consensus regarding the relationship between these factors, and the information available in what relates to chronic pain in the knee joint is even scarcer. The objective of this study was to describe and understand the relationship between the perceived social support and pain catastrophization in adults with chronic knee pain.

METHODS: Sociodemographic data were collected, and the West Haven-Yale Multidimensional Pain Inventory and Pain Catastrophizing Scale were completed by the participants. The sample included 28 participants attending daycare institutions in Aveiro, Braga and Leiria districts (Portugal).

RESULTS: Seventy-five percent of the participants presented clinically significant catastrophization, and $64.3 \%$ reported high perceived social support. There is a direct relationship between high catastrophization and frequent solicitations and distraction responses. Conversely, an inverse association between high catastrophization levels and infrequent negative responses was observed in the collected sample.

CONCLUSION: Useful social support contributes to a maladaptive response to pain by increasing catastrophization levels, and the catastrophic response may be a way to ask for support. There is a direct association between the perceived social support and the catastrophization of chronic knee pain in the participants. However, the association between these variables was

Bruna Almeida - (Dhttps://orcid.org/0000-0002-6501-7263

Adriana Capela - (Dhttps://orcid.org/0000-0001-7725-5675;

Joana Pinto - Dhttps://orcid.org/0000-0001-6234-8326;

Vânia Santos - (1)https://orcid.org/0000-0002-8497-3234;

Cândida G. Silva - Dhttps://orcid.org/0000-0002-7092-1169;

Marlene Cristina Neves Rosa - (Dhttps://orcid.org/0000-0001-8276-655X.

1. Instituto Politécnico de Leiria, Escola Superior de Saúde, Leiria, Portugal.

2. Universidade de Coimbra, Centro de Química de Coimbra, Coimbra, Portugal.

3. Instituto Politécnico de Leiria, Escola Superior de Saúde, CiTechCare, Leiria, Portugal.

Submitted in August 06, 2018.

Accepted for publication in December 14, 2018.

Conflict of interests: none - Sponsoring sources: none

Correspondence to:

Rua General Norton de Matos, Apartado 4133

2411-901 Leiria, Portugal.

E-mail: marlene.rosa@ipleiria.pt

(C) Sociedade Brasileira para o Estudo da Dor poor/low evidencing the need to consider other factors in the catastrophization study.

Keywords: Catastrophization, Chronic pain, Perceived social support.

\section{RESUMO}

JUSTIFICATIVA E OBJETIVOS: Tanto a catastrofização como o suporte social influenciam os resultados na saúde de indivíduos com dor crônica. Porém, não há consenso sobre a relação entre esses fatores, sendo escassa a informação direcionada à articulação do joelho. O objetivo deste estudo foi descrever e compreender a relação entre o suporte social percebido e a catastrofização da dor em idosos com dor crônica do joelho.

MÉTODOS: Foi feita a coleta de dados sociodemográficos, em conjunto com o preenchimento dos instrumentos West Haven-Yale Multidimensional Pain Inventory e Pain Catastrophizing Scale pelos participantes. A amostra foi constituída por 28 participantes, institucionalizados em regime de centro de dia dos distritos de Aveiro, Braga e Leiria (Portugal).

RESULTADOS: Setenta e cinco por cento dos participantes apresentaram catastrofização clinicamente significativa e 64,3\% referiram alto suporte social percebido. Verificou-se uma relação diretamente proporcional entre a elevada catastrofização e as respostas solícitas e de distração frequentes. Contrariamente, existe uma associação inversamente proporcional entre o elevado nível de catastrofização e as respostas negativas pouco frequentes na amostra recolhida.

CONCLUSÃO: O suporte social útil contribui para uma resposta desadaptativa à dor, pelo aumento dos níveis de catastrofização, podendo a resposta catastrófica constituir um meio para solicitar apoio. Denota-se uma associação diretamente proporcional entre o suporte social percebido e a catastrofização da dor crônica do joelho nos participantes. Contudo, a relação demonstrou ser pobre/baixa, evidenciando a necessidade de considerar outros fatores no estudo da catastrofização.

Descritores: Catastrofização, Dor crônica, Suporte social percebido.

\section{INTRODUCTION}

Chronic pain (CP) is a world public health problem ${ }^{1,2}$. Currently, CP is defined by lasting longer than three months, not considering other aspects ${ }^{2}$. In Portugal, $37 \%$ of the adult population suffers from CP, resulting in a strong personal and social impact $^{1,2}$. Chronic pain in the knee in adults is common around the 
world, with the highest percentage attributed to osteoarthritis, a chronic, progressive condition strongly correlated with aging ${ }^{3-5}$. Considering the several physiological mechanisms that contribute to musculoskeletal $\mathrm{CP}$, the current conceptual pain models include a biopsychosocial approach that involves reciprocal interactions between biological, psychological and social factors ${ }^{6-8}$. In the context of psychological factors, catastrophization is defined as an overly negative and unreal mental state that arises during the $\mathrm{CP}$ experience or its anticipation. Catastrophization encompasses three dimensions: rumination or obsession related to pain; magnification or exaggeration in valuing the threat it represents; and devaluation of the capacity/resources to control and manage the painful experience, ${ }^{9,10}$.

Regarding the relevant social factors in the conceptual models of pain, social support is of crucial importance ${ }^{11}$. Social support is characterized as a multifactorial concept, defined as the provision of resources between provider and receiver, to promote the welfare of the latter. Perceived social support is defined as the support that the individual perceives as available in case of need, while the social support received describes the support that was effectively provided ${ }^{12,13}$.

Two contradictory perspectives explain the relationship between social support and catastrophization in individuals with $\mathrm{CP}$. According to the Communal Coping Model, catastrophization arises as a way of the individual to request assistance and empathic responses from people of their social environment. These responses, especially when given by the spouse, can maintain or reinforce the expression of pain. On the other hand, other studies have shown that, when provided by individuals who do not belong to the marital relationship, higher levels of social support result in lower frequency and intensity of pain ${ }^{11,14,15}$.

Thus, it is fundamental to develop and contribute to new studies in this area in order to clarify the contradictory relationship among these factors that influence the health outcomes of individuals with $\mathrm{CP}$.

This study aimed to answer the question "What is the relationship between perceived social support and catastrophizing in individuals with $\mathrm{CP}$ in the knee"?

\section{METHODS}

A cross-sectional, descriptive study conducted with the participation of old people living in a daycare center of 3 institutions of the districts of Aveiro, Braga, and Leiria (Portugal). The inclusion criteria to participate in this study was age over 65 years and $\mathrm{CP}$ in the knee. The subjects were included in the sample after the explanation of the study procedure and completing the Free and Informed Consent Form (FICT), according to the Declaration of Helsinki. The cognitive impairment that prevented the coherent completion of the instruments was the exclusion criterion. The process of data collection included the authorization request to the institutions to collect the data and to the subsequent direct contact with the participants. Considering the probabilistic and statistical inference rules that ensure the trend to normality in samples that include 25 to 30 individuals, 30 individuals were recruited, but only 28 had stable health conditions during the direct contact of data collec- tion. After selecting the 28 individuals that fulfilled the criteria, the sociodemographic questionnaire for characterization of the sample and pain, previously constructed by the researchers, was applied. Of the pain-characterizing criteria, only the values for pain intensity were not obtained from the sociodemographic questionnaire, based on item 1 of part A of the West Haven-Yale Multidimensional Pain Inventory (WHY-MPI), validated to the Portuguese population?.

The evaluation of social support was also based on the WHYMPI, an instrument composed of 52 items, with scores from zero to six, distributed in three distinct parts. Items 5, 10 and 15 of part A were used to obtain the data on the evaluation of the support received by the participant. In addition, part $\mathrm{B}$, which is subdivided into negative responses (items $1,4,7,14$ ), solicitous responses (items 2, 3, 5, 8, 11 and 13) and distractive responses (items 6, 9, 12 and 14), allowed to obtain data related to the perceived social support. In the case of the predominance of negative responses, the perceived social support is said to be punitive, and when the frequency of solicitous and distractive responses is greater, the perceived social support is useful' ${ }^{9}$. The introductory part of this scale provided data on the significant person and the cohabitation of the participant and this person?

To evaluate pain catastrophization, the Portuguese version of the Pain Catastrophizing Scale (PCS) ${ }^{9}$ was used. This instrument consists of 13 items, with scores from zero to 4, with a total scoring between zero and 52. Higher scores determine higher levels of catastrophic thoughts. The level of catastrophization was considered clinically relevant when the total PCS score was greater than or equal to 30 . The 13 items of the PCS are grouped in the following dimensions: rumination (items 8, 9, 10 and 11), magnification (items 6, 7 and 13), and helplessness (items 1, 2, 3, 4, 5 and 12) , $^{9,16,17}$.

Study with ethical approval (document approval of the three institutions: 108.03 February 2018; 3454.032018; 054.27 January 2018). Clinical Trial Identifier: NCT02746835.

\section{Statistical analysis}

A descriptive analysis was performed of the data obtained from the sociodemographic questionnaire, WHY-MPI and PCS through the distribution of absolute and relative simple frequencies, central trend measures, such as the arithmetic mean, and dispersion measures as the standard deviation.

Table 1 shows the variables used for the analysis of the results regarding the perceived social support. For the variables perceived social support, negative responses, solicitous responses, distractive responses, rumination, magnification and helplessness, two levels of values were defined, based on the midpoint of the amplitude of values of the total score in each variable. For example, below and above the midpoint are considered, respectively, few and many negative, solicitous, or distractive responses. Regarding the pain catastrophizing data, the total PCS score was analyzed, as well as the catastrophization level defined based on the cut-off value of the scale.

The relationship between social support and pain catastrophization was assessed using the Pearson correlation coefficient between the total PCS score and the various dimensions of the part $\mathrm{B}$ of the WHY-MPI scale (negative, solicitous and distractive 
Table 1. Variables analyzed to study the relationship between the perceived social support and chronic pain catastrophization

\begin{tabular}{|c|c|c|}
\hline Instruments & Variables & Values \\
\hline Sociodemographic questionnaire & Marital status & Married; not married \\
\hline \multirow[t]{8}{*}{ WHY-MPI } & $\begin{array}{l}\text { Pain intensity } \\
\text { (Part A - Item 1) }\end{array}$ & $\begin{array}{l}\text { zero to } 6 \\
\text { (zero - No pain; } 6 \text { - Very intense pain) }\end{array}$ \\
\hline & \multirow[t]{2}{*}{$\begin{array}{l}\text { Perceived social support } \\
\text { (Part A - Items 5, } 10 \text { and 15) }\end{array}$} & $\begin{array}{l}\text { Total score } \\
\text { zero to } 18\end{array}$ \\
\hline & & $\begin{array}{l}\text { Level of perceived social support } \\
\text { Low (zero to } 9 \text { ) } \\
\text { High (10 to } 18 \text { ) }\end{array}$ \\
\hline & \multirow[t]{2}{*}{$\begin{array}{l}\text { Negative responses } \\
\text { (Part B - Items 1, 4, } 7 \text { and 14) }\end{array}$} & $\begin{array}{l}\text { Total score } \\
0 \text { to } 24\end{array}$ \\
\hline & & $\begin{array}{l}\text { Level of negative responses } \\
\text { Few (zero to } 9) \\
\text { Many (13 to } 24)\end{array}$ \\
\hline & \multirow[t]{2}{*}{$\begin{array}{l}\text { Distractive responses } \\
\text { (Part B - Items 6, 9, } 12 \text { and 14) }\end{array}$} & $\begin{array}{l}\text { Total score } \\
\text { zero to } 24\end{array}$ \\
\hline & & $\begin{array}{l}\text { Level of distractive responses } \\
\text { Few (zero to } 9) \\
\text { Many (13 to } 24)\end{array}$ \\
\hline & Significant person & $\begin{array}{l}\text { Father/mother, child, another relative; spouse; neighbor, } \\
\text { friend, partner/companion; house colleague; others }\end{array}$ \\
\hline \multirow[t]{5}{*}{ PCS } & Total score & zero to 52 \\
\hline & Catastrophization level & $\begin{array}{l}\text { Clinically not significant (zero to } 29 \text { ) } \\
\text { Clinically significant ( } 30 \text { to } 52 \text { ) }\end{array}$ \\
\hline & $\begin{array}{l}\text { Magnification } \\
\text { Items } 6,7 \text { and } 13\end{array}$ & $\begin{array}{l}\text { Magnification level: } \\
\text { Little (zero to 6) } \\
\text { A lot (7 to 12) }\end{array}$ \\
\hline & \multirow[t]{2}{*}{$\begin{array}{l}\text { Helplessness } \\
\text { Items 1, 2, 3, 4, } 5 \text { and } 12\end{array}$} & $\begin{array}{l}\text { Total score } \\
\text { zero to } 24\end{array}$ \\
\hline & & $\begin{array}{l}\text { Helplessness level: } \\
\text { Little (zero to 12) } \\
\text { A lot (13 to } 24)\end{array}$ \\
\hline
\end{tabular}

WHY-MPI = West Haven-Yale Multidimensional Pain Inventory; PCS = Pain Catastrophizing Scale.

responses). Additionally, the correlation between pain intensity and the total PCS score, with the various dimensions of part B of the WHY-MPI scale, was analyzed by calculating the Spearman correlation coefficient $(r)$. To interpret the values obtained, the following standard intervals were considered: poor correlation $(\mathrm{r}<0.30)$, weak (r: 0.30-0.50), moderate (r: 0.50-0.70), strong ( $\mathrm{r}$ : $0.70-0.90)$ and very strong $(r>0.90)^{18}$.

Based on the Communal Coping Mode, a cross-tabulation was constructed between the variables marital status (married, unmarried) and catastrophization level (clinically significant and not significant), to understand if the catastrophization of pain is superior among married individuals ${ }^{11}$.

All statistical procedures were performed with the IBM ${ }^{\circ}$ SPSS $^{\circ}$ Statistics software, version 23.

\section{RESULTS}

The sample consisted of $78.6 \%$ females and $21.4 \%$ males, with an average age of 79.25 years. Of the 28 individuals, $39.3 \%$ are widowers, and the percentage of married individuals (25\%) was 
also significant. Also, $64.3 \%$ of the respondents had only the first schooling cycle (4 years).

In relation to the characterization of pain, the localized pain (71.4\%), anterior $(60.7 \%)$ and continuous $(60.7 \%)$ predomi-

Table 2. Perceived social support

\begin{tabular}{lcc}
\hline Classes & Frequency & $\%$ \\
\hline WHY-MPI - Part A (items 5, 10 and 15) & & \\
Level of social support received & & \\
$\quad$ Few & 10 & 35.7 \\
Much & 18 & 64.3 \\
WHY-MPI - Part B & & \\
Negative responses & & \\
$\quad$ Few & 25 & 89.3 \\
$\quad$ Many & 3 & 10.7 \\
Solicitous responses & & \\
$\quad$ Few & 9 & 32.1 \\
$\quad$ Many & 19 & 67.9 \\
Distractive responses & & \\
$\quad$ Few & 17 & 60.7 \\
$\quad$ Many & 11 & 39.3 \\
\hline WHY-MPI = West Haven-Yale Multidimensional Pain Inventory.
\end{tabular}

Table 3. Pain catastrophization

\begin{tabular}{lc}
\hline Catastrophization & $\mathrm{n}=28$ \\
\hline Total PCS (mean \pm SD) & $35.14 \pm 10.28$ \\
Catastrophization level - frequency & $21(75 \%)$ \\
Clinically significant $(\geq 30)$ & $7(25 \%)$ \\
Clinically not significant $(<30)$ &
\end{tabular}

PCS = Pain Catastrophizing Scale.

Table 4. Catastrophization dimensions

\begin{tabular}{lcc}
\hline & Frequency $(\mathrm{n}=28)$ & $\%$ \\
\hline Rumination & & \\
Few & 9 & 32.1 \\
Much & 19 & 67.9 \\
Magnification & & \\
Few & 8 & 28.6 \\
Much & 20 & 71.4 \\
Helplessness & & \\
Few & 6 & 21.4 \\
Much & 22 & 78.6 \\
\hline
\end{tabular}

nated, being more frequent in the right knee or bilateral (35.7\%). Concerning pain intensity, $39.3 \%$ of the participants had significant pain, evaluated in 4 on a scale from zero to 6 .

More than half of the participants $(57.14 \%)$ identified their father, mother, child or another relative as their significant person, and the percentage of the sample who mentioned the spouse $(25 \%)$ is still considerable. About $75 \%$ of the participants live with the significant person.

Regarding the evaluation of the social support received by the participant, $64.3 \%$ said they have a lot of support (Table 2). Regarding the responses by the significant person, the majority said that they had few negative responses (89.3\%), many solicitous responses $(67.9 \%)$ and few distractive responses $(60.7 \%)$.

The total PCS score showed an average of 35.14 , a value that is a predictor of a clinically significant level of catastrophization (Table 3). It is worth mentioning that $75 \%$ of the participants presented a clinically significant catastrophization.

Concerning the different dimensions of the PCS scale (Table $4)$, the majority of the participants indicated much rumination (67.9\%), much magnification (71.4\%) and much helplessness $(78.6 \%)$, with no specific trend to any of the dimensions.

The data of the present study showed a poor correlation $(r=0.219)$ between: (i) pain intensity and total PCS score; (ii) pain intensity and negative $(r=0.001)$, solicitous $(r=0.191)$ and distractive $(r=0.120)$ responses of the significant person. There was also a positive correlation between the total PCS score and the solicitous and distractive responses, poor $(r=0.209)$ and weak $(r=0.342)$, respectively, with higher values for the distractive responses. The correlation between the total PCS score and the negative responses was poor and negative $(r=-0.162)$. Concerning the relation between the various dimensions of part $\mathrm{B}$ of the WHY-MPI scale, there was a moderate positive correlation $(\mathrm{r}=0.624)$ between the solicitous and distractive responses and a moderate negative correlation $(\mathrm{r}=-0.591)$ between the solicitous and negative responses (Table 5).

In order to understand the data trend regarding catastrophization among married individuals, and knowing that they identified the spouse as the significant person, the marital status and the level of catastrophization were cross-checked showing an evident trend between the analyzed variables (Table 6).

Table 5. Correlation between pain intensity and the total score of the Pain Catastrophizing Scale and the dimensions of the social support and the correlation between the total score and the dimensions of the perceived social support

\begin{tabular}{|c|c|c|c|c|}
\hline $\begin{array}{l}\text { Spearman correlation } \\
(\mathrm{n}=28)\end{array}$ & Total PCS & Negative responses & Solicitous responses & Distractive responses \\
\hline $\begin{array}{l}\text { Pain intensity } \\
\text { Coefficient of correlation }\end{array}$ & 0.219 & 0.001 & 0.191 & 0.120 \\
\hline Pearson correlation $(n=28)$ & Total PCS & Negative responses & Solicitous responses & Distractive responses \\
\hline $\begin{array}{l}\text { Total PCS } \\
\text { Coefficient of correlation }\end{array}$ & & -0.162 & 0.209 & 0.342 \\
\hline $\begin{array}{l}\text { Negative responses } \\
\text { Coefficient of correlation }\end{array}$ & & & $-0.591^{\star *}$ & $-0.427^{\star}$ \\
\hline $\begin{array}{l}\text { Solicitous responses } \\
\text { Coefficient of correlation }\end{array}$ & & & & $0.624^{\star *}$ \\
\hline $\begin{array}{l}\text { Distractive responses } \\
\text { Coefficient of correlation }\end{array}$ & & & & \\
\hline
\end{tabular}


Table 6. Cross-check between the cutoff value of the Pain Catastrophizing Scale and married status

\begin{tabular}{lc}
\hline Cross-tabulation & $\begin{array}{c}\text { Marital status: } \\
\text { married }(n=7)\end{array}$ \\
\hline Catastrophization level & \\
Clinically significant & 4 \\
Clinically non-significant & 3 \\
\hline
\end{tabular}

\section{DISCUSSION}

Most of the studies in this area state that the perceived social support has been identified as influential in the management of pain in chronic situations and that catastrophization negatively affects the health outcomes of people with pain ${ }^{11,14,15}$. However, the relationship between the perception of social support and the catastrophizing levels in individuals with chronic knee pain is not consensual in the literature.

From the results obtained in this study, it was possible to observe that the majority of the sample presented clinically significant catastrophization (Table 3), with a greater impact on the helplessness dimension. These results are consistent with a study that investigated the associations among the catastrophizing dimensions, concluding that helplessness plays a predominant role in catastrophization in individuals with $\mathrm{CP}^{19}$. Regarding the perceived social support, it can still be observed that most of the participants had a greater frequency of solicitous and distractive responses in comparison with the frequency of negative responses (Table 2). The same was seen in a study conducted by Gauthier al. ${ }^{20}$ that showed a greater frequency of solicitous and distractive responses. In addition, more than half of the sample of this study referred to the social support received as frequent.

According to the literature, catastrophization is associated with the activation of the brain areas involved in response to pain, being a non-adaptive behavior aiming at the attainment of social support, capable of increasing the intensity of pain. However, the literature points out that the higher the intensity of pain, the greater the inhibition of the activated brain areas. Accordingly, the results of this study showed a positive but poor relationship between catastrophization and pain intensity, which can be explained by the significant level of pain intensity ${ }^{10,21,22}$. Thus, one can conclude that the reading and interpretation of catastrophization by health professionals should be performed considering two axes: the level of social support and the quantification of the perceived pain, the latter using the analog scales frequently used in the clinical context. In the present study, the results showed a directly proportional relationship between high catastrophization and frequent solicitous and distractive responses as well as an inversely proportional association between a high catastrophizing level and less frequent punitive responses. Individuals with more frequent solicitous and distractive responses had more catastrophization and individuals with more frequent negative responses had less catastrophization. Previous studies in this area have found a similar data trend explaining that in the context of CP, solicitous and distractive responses to pain behaviors and absence of negative responses may reinforce catastrophization $^{11,20}$. Thus, in the cases analyzed, useful social support, in which solicitous and distractive responses predominate, predisposes to a non-adaptive response to pain due to the increase in catastrophization levels. Taking into account the characteristics of the sample of this study, where more than $80 \%$ of the participants identified the significant person as a relative, the data obtained seem to reinforce that the care provided by a family member reinforces the expression of pain, answering the original question of this study. If the health professional is aware of this reality and some coping strategies and caregiver education, he/she can play a relevant role in the management of pain catastrophization.-

This study had some limitations. On the one hand, since it was a cross-sectional study, it did not allow to state the directionality of the relations. On the other hand, the size of the sample and the concentration of ages in a high and narrow age group can also be a limitation to the study, not allowing to generalize the conclusions obtained for the remaining population. Also, the disparity between the number of married individuals and individuals of other marital status did not allow conclusions to be compared with the Communal Coping Model. In addition, with only self-reported data from participants about social support, it was not possible to know if the catastrophization of pain was associated with the perceived support responses or its actual provision by the significant person. Therefore, in a clinical context, it should be considered not only the patient's perspective but also of the significant person to understand the quality of the relationship between them and the level of support effectively provided in the real context of the individual's life.

\section{CONCLUSION}

In this study, the association between the perceived social support and the catastrophization of knee $\mathrm{CP}$ was directly proportional but low.

\section{REFERENCES}

1. IASP. How Prevalent Its Chronic Pain? Pain Clin Update. 2003;XI(2):1-4.

2. Azevedo LF, Costa-Pereira A, Mendonça L, Dias C, Castro-Lopes JM. Epidemiology of chronic pain: a population-based nationwide study on its prevalence, characteristics and associated disability in Portugal. J Pain. 2012;13(8):773-83.

3. Ilori T, Ladipo MM, Ogunbode AM, Obimakinde AM. Knee osteoarthritis and perceived social support amongst patients in a family medicine clinic. S Afr Fam Pract. 2016;1(1):1-5.

4. McDougall JJ. Arthritis and pain. Neurogenic origin of joint pain. Arthritis Res Ther. 2006;8(6):220.

5. Quicke JG, Foster NE, Thomas MJ, Holden MA. Is long-term physical activity safe for older adults with knee pain? A systematic review. Osteoarthritis Cartilage. 2015;23(9):1445-56.

6. Adams LM, Turk DC. Psychosocial factors and central sensitivity syndromes. Cur Rheumatol Rev. 2015;11(2):96-108.

7. Edwards RR, Cahalan C, Mensing G, Smith M, Haythornthwaite JA. Pain, catastrophizing, and depression in the rheumatic diseases. Nat Rev Rheumatol. 2011;7(4):216-24.

8. Gatchel RJ. The biopsychosocial model of chronic pain. In: Clinical Insights, editor The biopsychosocial model of chronic pain. 2013. 5-17p.

9. Azevedo LF, Pereira AC, Dias C, Agualusa L, Lemos L, Romão J, et al. Questionários sobre dor crónica. tradução, adaptaçáo cultural e estudo multicêntrico de validação de instrumentos para rastreio e avaliaçâo do impacto da dor crónica. Dor. 2007;15:6-37.

10. Leung L. Pain catastrophizing: an updated review. Indian J Psychol Med. 2012;34(3):204-17.

11. López-Martínez AE, Esteve-Zarazaga R, Ramírez-Maestre C. Perceived social support and coping responses are independent variables explaining pain adjustment among chronic pain patients. J Pain. 2008;9(4):373-9.

12. Bogossian FE. Social support: proposing a conceptual model for application to midwifery practice. Women Birth. 2007;20(4):169-73.

13. Cramer D, Henderson S, Scott R. Mental health and adequacy of social support: a 
four-wave panel study. Br J Soc Psychol. 1997;35(Pt 2):285-95.

14. Che X, Cash R, Fitzgerald P, Fitzgibbon BM. The social regulation of pain: autonomic and neurophysiological changes associated with perceived threat. J Pain. 2018;19(5):496-505.

15. Sullivan MJ, Thorn B, Haythornthwaite JA, Keefe F, Martin M, Bradley LA, et al. Theoretical perspectives on the relation between catastrophizing and pain. Clin J Pain. 2001;17(1):52-64.

16. Sullivan MJ, Adams H, Sullivan ME. Communicative dimensions of pain catastrophizing: social cueing effects on pain behaviour and coping. Pain. 2004;107(3):220-6.

17. Sullivan MJ. The Pain Catastrophizing Scale. User Manual. 2009. 3-22p.

18. Broekmans T, Gijbels D, Eijnde BO, Alders G, Lamers I, Roelants M, et al. The relationship between upper leg muscle strength and walking capacity in persons with multiple sclerosis. Mult Scler. 2013;19(1):112-9.
19. Adachi T, Nakae A, Maruo T, Shi K, Maeda L, Saitoh Y, et al. The relationships between pain catastrophizing subcomponents and multiple pain-related outcomes in Japanese outpatients with chronic pain: a cross-sectional study. Pain Pract. 2018;17 [Epub ahead of print].

20. Gauthier LR, Rodin G, Zimmermann C, Warr D, Librach SL, Moore M, et al. The communal coping model and cancer pain: the roles of catastrophizing and attachment style. J Pain. 2012;13(12):1258-68.

21. Krahé C, Springer A, Weinman JA, Fotopoulou A. The social modulation of pain: others as predictive signals of salience - a systematic review. Fornt Hum Neurosci. 2013;7:386.

22. Suso-Ribera C, García-Palacios A, Botella C, Ribera-Canudas MV. Pain catastrophizing and its relationship with health outcomes: does pain intensity matter? Pain Res Manag. 2017;2017:9762864. 